\title{
The Design - Reality Gap: The Impact of Stakeholder Strategies on IS Implementation in Developing Countries
}

\author{
Ranjan Vaidya, Michael D. Myers, and Lesley Gardner \\ Department of Information Systems \& Operations Management, University of Auckland \\ Business School, Owen G Glenn Building, 12 Grafton Road, Auckland, New Zealand 1010 \\ Tel.: +64 22587644, +64 9373 7599, Ext.: 87468, \\ Tel.: +64 9373 7599, Ext.: 86638 \\ \{r.vaidya, m.myers, l.gardner\} @auckland.ac.nz
}

\begin{abstract}
A deep understanding of stakeholder strategies can be a powerful tool in helping IS researchers understand the realities of IS design and implementation in developing countries. We discuss the strategies used by stakeholders during the implementation of the first state government owned agricultural marketing information system project in India. Our main findings are that, while some stakeholder strategies were consistent with the implementation of the new system, most stakeholder strategies were not. Our findings may have important implications for the design and implementation of information systems in other developing countries.
\end{abstract}

Keywords: Stakeholder theory, Stakeholder strategy, information systems, interpretive case study, developing countries.

\section{Introduction}

The failure of ICT projects is a dominant theme within the ICT for development (ICT4D) research stream (Avgerou, 2008). Studies have related IS failure with stakeholder issues such as stakeholder expectations, impact on stakeholder interests and their involvement in IS design and implementation (Bailur, 2006; Bhatnagar, 2007; Krishna \& Walsham, 2005; Kumar \& Best, 2006; Lyytinen, 1988; Lyytinen \& Hirschheim, 1987; Scholl, 2002; Walsham \& Sahay, 2006).

Stakeholder issues have received considerable attention in IS, but the question that how stakeholders achieve their objectives through various strategies has been a neglected theme in information systems in developing countries (ISDC) research. This is in spite of the fact that study of stakeholder strategies provides useful insight on areas of IS intervention. Our research question is how stakeholder strategies impact ICT4D projects in developing countries.

We attempt to answer this question by the model proposed by Frooman (Frooman, 1999; Frooman \& Murrell, 2005) as the theoretical basis for studying the stakeholder strategies in IS implementation at an agricultural marketing board in India. The board initiated the implementation in 2003 with an objective of connecting the various government agricultural markets of the state. The project involves four primary stakeholders; the farmers, government officers, the traders and the private partner company 
implementing the information system. We discuss the strategies of these stakeholders in relation to the success or failure of the information system.

The paper proceeds as follows. In the next section we briefly review the stakeholder strategies in the background of stakeholder theory. In section three we discuss the interpretive case study method used in the current research. Section four presents the case study. In section five we present our analysis of the study. The final section is the discussion and conclusion.

\section{Stakeholder Strategies in Is Implementation}

Stakeholder theory provides a theoretical framework for understanding stakeholders. Conflicting stakeholder interests provide the premises for the stakeholder theory and its ultimate concern is improvement in organizational ethics (Kaler, 2002; Phillips, Freeman, \& Wicks, 2003). There are three distinct approaches to the stakeholder theory namely descriptive, instrumental and normative. The descriptive approach is concerned with the description of stakeholders and their conflicting interests. The instrumental approach views the stakeholders as a means for achieving the organizational objectives. The normative approach concerns itself with moral and ethical issues of stakeholder management and is at the core of both the descriptive and instrumental approaches (Kaler, 2002; Phillips, et al., 2003). According to Frooman (1999) stakeholder theory provides a framework for answering there basic stakeholder questions namely; who are the stakeholders? what are their interests? And how do they achieve these interests? Each of these questions has led to the development of separate research streams namely stakeholder identification, stakeholder interests and stakeholder strategies. While the first two questions have received adequate attention from researchers, the third has been left largely unexplored (Frooman \& Murrell, 2005). Hence the contribution of this paper is that it studies the stakeholder strategies in ICT4D setting.

In the stream of management, this limitation in stakeholder theory research has been recognized and attempts have been made to provide theoretical frameworks for studying stakeholder strategies (Frooman, 1999; Frooman \& Murrell, 2005; Hendry, 2005). These attempts are primarily based on the model proposed by Frooman (1999). In this model the choice of stakeholder strategy is determined by the resource relationship between the organization and stakeholders. Through control of various resources (physical, financial or informational) the stakeholders influence each other's decision making. The stakeholders may use direct strategies or indirect strategies. In direct strategies the stakeholders withhold the resources and force their dictates to the organization. In indirect strategies the decision making is influenced through involvement. The attributes proposed by Mitchell et al (1997) namely power, legitimacy and urgency may be used to understand the claims of the stakeholders on resources.

Frooman (1999) reviews the various strategies that are used by stakeholders such as boycotts and proxy resolutions, coercion or compromise, divestures, formation of coalitions, usage and withholding of resources, vendettas, use of allies, etc. Figure 1 below presents the model proposed by Frooman (1999) and presents the power dynamics between the organization and the stakeholder, while the figure 2 presents the strategy used by the stakeholder. 


\begin{tabular}{|c|c|c|c|}
\hline \multicolumn{4}{|c|}{ Typology of Resource Relationships } \\
\hline \multirow{2}{|c|}{} & \multicolumn{2}{|c|}{ Is the stakeholder dependent on the firm } \\
\cline { 3 - 4 } & No & Yes \\
\hline \multirow{2}{*}{ Is the firm dependent } & No & Low interdependence & Firm power \\
\cline { 2 - 4 } on the stakeholder & Yes & Stakeholder power & High interdependence \\
\cline { 2 - 4 }
\end{tabular}

Fig. 1. Frooman (1999) typology of resource relationship

\begin{tabular}{|c|c|c|c|}
\hline \multicolumn{4}{|c|}{ Typology of Influence Strategies } \\
\hline \multirow{2}{|c|}{} & \multicolumn{2}{|c|}{ Is the stakeholder dependent on the firm } \\
\cline { 3 - 4 } & No & Yes \\
\hline \multirow{2}{*}{$\begin{array}{c}\text { Is the firm dependent } \\
\text { on the stakeholder }\end{array}$} & No & Indirect/ withholding & Indirect/ usage \\
\cline { 2 - 4 } & Yes & Direct/ withholding & Direct/ usage \\
\hline
\end{tabular}

Fig. 2. Frooman (1999) typology of choice of strategy

The model proposed by Frooman (1999) has some limitations. We highlight these as follows:

1. First, the unit of analysis in Frooman's model is organization. This is highlighted by the use of the term "stakeholder theory of firms" in place of "stakeholder theory" in various studies (Brenner et al in Mellahi \& Wood, 2003). A general criticism of the stakeholder theory is that it has been applied to a formally constituted collective such as an organization with its suppliers. According to Preston \& Sapienza (1990) "the stakeholder model is an organizational construct". However ICT4D projects often involve stakeholders that lack a clear organizational structure such as traders, villagers, farmers, urban poor, city dwellers, etc. There are various examples of research studies that present examples of such informally existing groups such as poor women, farmers, pensioners, school teachers, drivers and vehicle owners, students, etc (Best \& Kumar, 2008; Ciborra, 2005; Heeks \& Arun, 2010; Kumar \& Best, 2006; Lewis \& Madon, 2004). Stakeholder literature often regards such stakeholders as secondary in spite of the fact that they are the primary stakeholders in these projects (Zietsma \& Winn, 2008). We suggest that the unit of analysis for stakeholder strategies should not be limited to the organization, but expanded to include other kinds of collectives such as farmers.

2. Second, Frooman's model is based on a single construct i.e. resource dependence. It has been accepted by Frooman (Frooman \& Murrell, 2005) that resource dependence is just one construct as is mentioned "Specifically, we test whether one component of a firm's relational setting-its resource relationships with 
stakeholders - is a determinant of the choice of strategies stakeholders use to influence a firm". Moreover other studies have shown that the strategies that stakeholders choose are not based on resource requirements only (Mellahi \& Wood, 2003). Cultural factors may also play an important role in influencing the decision making (Walsham \& Sahay, 1999).

3. Third, empirical studies have indicated that the model proposed by Frooman is a parsimonious model but does not account for the use of multiple strategies simultaneously (Hendry, 2005).

In this paper we try to overcome these limitations by studying the strategies for each stakeholder and we do not bind ourselves to the construct of resource dependence alone. Also our objective in this paper is not to present a refined model of stakeholder strategies and the conditions in which a particular strategy is chosen. Instead we discuss the strategies from the point of view of their impact on the success of information system. Our theoretical contribution is twofold. First we demonstrate that strategies are a means for understanding the complex reality in ICT4D projects. Second we attempt to identify the attributes of strategies that negatively impact IS success. The theoretical model that we propose for information system development, implementation and use is presented in figure 3 below. The model presents stakeholder strategies as a mediating construct between IS design \& implementation and social reality. The bidirectional arrow between stakeholder strategies and social reality suggests that stakeholder strategies both cause and are caused by social realities and hence reflect the realities of IS design and implementation. The other bidirectional arrow suggests that IS design and implementation and stakeholder strategies should inform each other.

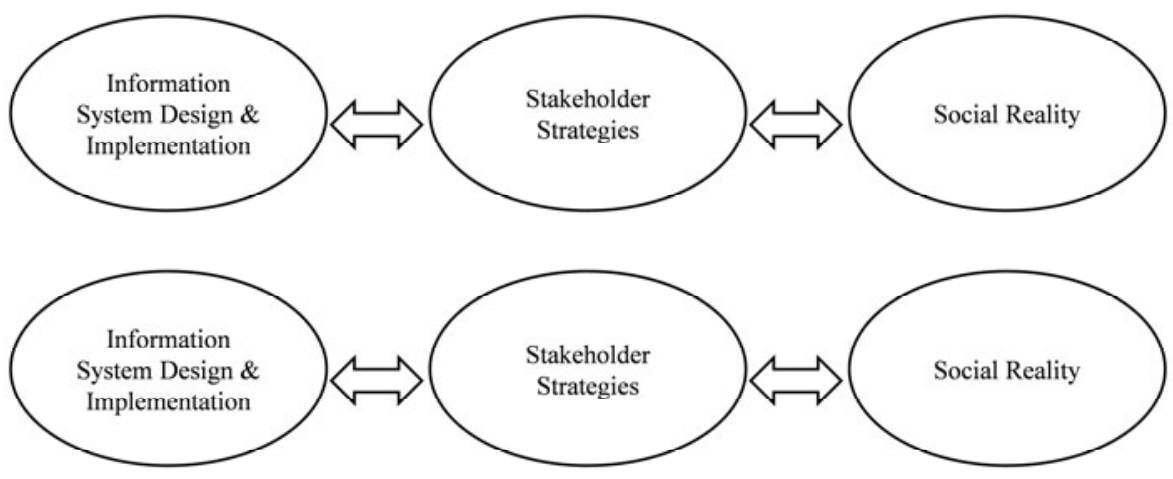

Fig. 3. Stakeholder strategy based model for IS design and implementation

\section{Research Method}

Our overall approach in the present study has been qualitative, as qualitative research helps the researchers to understand the behaviour of people in the light of their context and values (Myers, 2009). Our epistemological stance is interpretive (Klein 
\& Myers, 1999; Nandhakumar \& Jones, 1997; Orlikowski \& Baroudi, 1991). One reason for choosing an interpretive approach is that interpretive research does not require the formulation of constructs a priori (Cavaye, 1996). Moreover interpretive case studies are well suited for studying the phenomenon in context (Cavaye, 1996; Klein \& Myers, 1999; Walsham, 2006).

The data for the study was collected by one of the authors for a six month period in 2009 and 2010. The data was collected from semi structured interviews, observations, field notes and government records. Overall 27 interviews were conducted with farmers, government officers, private partners and traders. Table 1 presents the distribution of interviews:

Table 1. List of stakeholder Strategies

\begin{tabular}{|l|c|}
\hline \multicolumn{1}{|c|}{ Stakeholder } & Interviews \\
\hline Government employees & 7 \\
\hline Private partners & 9 \\
\hline Traders & 2 \\
\hline Farmers & 9 \\
\hline
\end{tabular}

The interviews with the government officers and private partners were undertaken at different levels of hierarchy. The interviews with the farmers and traders were undertaken at market yards as well as their villages. These interviews and field visits were carried out at six different yards in the state. The interviews lasted from between 30 minutes to 2 hours. The interviews with all the respondents were undertaken in Hindi language. The interviews with the farmers were recorded while notes were taken for the interviews with other stakeholders. The data was analysed with NVivo software. Certain documents and reports such as project reports, yard details, Performa, reports generated by IS, etc were collected both from the office of the private partners as well as the government offices.

\section{Case Description}

This case study describes the implementation of an information system at an agricultural marketing board in one of the states of India. The project is unique as it is the first effort by state government in India to integrate the government owned market yards through the use of information and communication technologies (ICT). These yards are a common meeting platform for the traders and the farmers. 


\subsection{The State}

The state under study is one of the twenty eight states of India. The total population of the state is over 60 million of which over seventy percent is rural. There are over fifty thousand villages in the state and agriculture is a major source of livelihood. The state is a leading producer of various agricultural commodities in India namely soybeans, grams, oilseeds and pulses. Local farmers sell their commodities to the traders in the government owned market yards. These yards are managed by a committee comprising of the traders, farmers and government officers.

\subsection{History of Market Yards}

The agricultural commodity markets in India were regulated through the Bombay Cotton Market Act of 1927. The act specified the establishment of certain open yards where un-baled cotton of the farmers could be marketed (Singh, 2007). This resulted in creation of market yards where the farmers sold their commodities to the traders through commission agents. Initially these yards were completely autonomous bodies but in early seventies the state government created a state level agricultural marketing board for controlling the yards. This saw some changes in the yard administration. A common exemplary code of rules was prescribed for all yards of the state, the process of commissioning was banned and the middle and upper management employees of the yard were absorbed as board employees.

\subsection{Agricultural Marketing Board}

The Agricultural Marketing Board is the apex organization in the state responsible for providing marketing support to the farmers. The board can be viewed as a three level organization. The first level comprises of the market yards where the trade transactions take place. At the second level are the regional offices that control and monitor the yards. At the third level is the head office which is located in the state capital. At present there are over two hundred yards in the state.

\subsection{Process of Trade Transactions}

The trade transactions at the yard includes processes of auctioning of the commodities, weighing of the commodities, payments to the farmers and depositing of the service charges by the traders. These are described in steps below:

- $\quad$ Step 1: The farmers enter the yards and are issued an entry slip.

- Step 2: After entry farmers display their commodities for sale to traders at designated spots. A yard employee such as an inspector conducts the auction in front of the traders and the farmers.

- Step 3: After the auction is over the commodity is weighed by the contractual labourers and the weight is certified by a weight certificatory.

- Step 4: The farmer collects payment from the trader. 
- Step 5: The trader is required to deposit the service charges payable to the yard committee. The service charge is two percent of the payment value ${ }^{1}$. After the service charge is deposited, the trader is issued a 'no objection certificate' by the yard authorities. The trader is required to show this certificate for transporting the commodities to other states.

\subsection{Problems in Manual System}

The process of selling and buying at the yard is one which involves various sub processes such as auctioning, weighing, etc. This is exacerbated by complicated documentation that needs to be reconciled for the calculations of service charges payable by the traders. Often the data may not reconcile and this is a major embarrassment for the government employees. Such a situation is exploited by the traders who manipulate the trader records and under report their transactions. Furthermore, the farmers travel long distances to reach the market yards. Often the rates are unfavourable and they end up with losses. There are conflicts between the various stakeholders on issues related to quality of the commodity, payments to farmers, etc. Thus the exploitation of the farmers provided the overall rationale for initiating the computerization project in 2003.

\subsection{Computerization of Yards}

The project aimed at capturing the data of all the processes electronically through computer terminals, hand held electronic terminals and electronic weigh bridges. At each yard the data is uploaded to a central server and is redistributed to various yards, inter-state check posts and the board head office. The data is also displayed on the website of the board. At each computerized yard, the processed data (auction rates, etc) are displayed on TV sets. The project is being implemented in phases and presently the data is captured from over sixty market yards.

The project has been conceived and executed by the board and a consortium of organizations. The entire investment on hardware, software, manpower and maintenance has been done by the private partners. The board pays the vendor a percentage of the total service charges collected.

An evaluation by the Department of Information Technology, Ministry of Information and Communication Technology, Government of India in 2008 indicates that the project has been successful in providing timely payments to the farmers, reducing the errors in transactions and providing an overall improved quality of services (DIT, 2008 pp 92). Empirical evidence however suggests that there are certain issues with IS implementation.

\section{Case Analysis}

The farmers, government officers, traders and the private partners are the primary stakeholders on the basis of the dimensions of power, legitimacy and urgency

\footnotetext{
${ }^{1}$ A further 0.20 percent fee is charged from the traders and is contributed in the fund for the homeless people. Thus a trader pays a total fee of 2.20 percent.
} 
(Mitchell, et al., 1997). These stakeholders have different contexts and requirements. A poor farmer for example approaches the yard when there is a need to repay some loan or there is a social function in his family. The government officer gets his income from the income of the yard. The private partner's revenue is based on certain percentage share of the yard income. The trader obviously makes his profit through the yard and thus has immense stakes in the working of the yard.

These stakeholders use various strategies to serve their interests in the yard. These strategies have positive, negative or neutral impacts on the success of information systems. Table 2 below lists the various positive, negative and neutral strategies adopted by the stakeholders. One the left hand side of the table the impact of the strategy is presented as negative, positive or neutral. Corresponding to the four stakeholders, each of the negative, positive and neutral strategy is presented. For example the farmers use negative impact strategies or quality manipulations and signing multiple contracts. The positive impact strategies of the farmers include stocking and mortgaging of commodities. The neutral strategies include exercise of patience and agitations.

Table 2. List of stakeholder Strategies

\begin{tabular}{|c|c|c|c|c|}
\hline Strategy impact & FARMERS & TRADERS & $\begin{array}{l}\text { PRIVATE } \\
\text { PARTNERS (PP) }\end{array}$ & $\begin{array}{l}\text { GOVERNMENT } \\
\text { OFFICERS }\end{array}$ \\
\hline \multirow{2}{*}{ NEGATIVE } & $\begin{array}{c}\text { Quality } \\
\text { Manipulations }\end{array}$ & $\begin{array}{c}\text { Smuggles } \\
\text { Commodity }\end{array}$ & $\begin{array}{c}\text { Deploys } \\
\text { inadequate staff }\end{array}$ & $\begin{array}{l}\text { Ignores the } \\
\text { rules/regulations }\end{array}$ \\
\hline & $\begin{array}{c}\text { Signing multiple } \\
\text { contracts }\end{array}$ & $\begin{array}{l}\text { Under } \\
\text { reporting }\end{array}$ & $\begin{array}{c}\text { Deploys } \\
\text { untrained staff }\end{array}$ & $\begin{array}{c}\text { Apathetic to } \\
\text { subordinate needs }\end{array}$ \\
\hline \multirow[b]{2}{*}{ POSITIVE } & Stocking & Stocking & $\begin{array}{l}\text { Facilitates free } \\
\text { communication }\end{array}$ & $\begin{array}{c}\text { Observes } \\
\text { suspicious traders }\end{array}$ \\
\hline & $\begin{array}{l}\text { Mortgages the } \\
\text { commodity }\end{array}$ & $\begin{array}{c}\text { Lesser } \\
\text { margins and } \\
\text { higher } \\
\text { transactions }\end{array}$ & $\begin{array}{l}\text { Conveys to } \\
\text { employees the } \\
\text { differences in } \\
\text { govt \& PP }\end{array}$ & $\begin{array}{l}\text { Resorts to clauses } \\
\text { of contract in } \\
\text { dealing with PP }\end{array}$ \\
\hline \multirow[t]{2}{*}{ NEUTRAL } & $\begin{array}{c}\text { Maintains } \\
\text { patience in some } \\
\text { processes }\end{array}$ & $\begin{array}{l}\text { Advance } \\
\text { payments }\end{array}$ & $\begin{array}{l}\text { Maintains its } \\
\text { work culture }\end{array}$ & $\begin{array}{c}\text { Replies to internal } \\
\text { notices } \\
\text { diplomatically }\end{array}$ \\
\hline & Agitations & $\begin{array}{l}\text { Blames the } \\
\text { government }\end{array}$ & $\begin{array}{l}\text { Blames the } \\
\text { government }\end{array}$ & $\begin{array}{l}\text { Levies penalty on } \\
\text { the traders }\end{array}$ \\
\hline
\end{tabular}

Given space limitations, we will discuss only those strategies that have a negative impact on the information system below. Of course, it is the negative strategies that cause most of the difficulties with the implementation of the system. 


\subsection{Farmer Strategies}

Often the farmers manipulate the commodity quality by mixing the old harvest with the new. By doing so their commodity is sold at higher rates. Sometimes such quality manipulations are detected by the traders and this is a major source of conflict at the yard. These manipulations are sometimes intentional and sometimes because of contextual factors. One of the farmers explained the context of these quality manipulations as under:

"See in this field you will observe that the wheat crop is not homogenous. Some grains have grown tall while others are stunted. The farmer here has mixed different seed varieties. He might not have enough money to buy new seeds. Or maybe his intention is to sell the commodity in the yard. So if the higher quality grains are mixed with the lower quality, there are chances that the commodity can be sold for higher rates." According to a private partner employee:

"Often the farmers have old stock of commodity. Such stock has lost its lustre and the farmers know that it won't yield them a good price. So the crafty farmers sometimes mix the old stock with the new. Sometimes various farmers share the lorry and their produce gets mixed up and results in a mixed quality".

One government officer described a typical situation arising out of such quality manipulation:

"A farmer brought some chillies for selling. The sample that was shown to the trader had a very good quality. The trader quoted a rate of 4000 rupees a quintal. But beneath the good quality there was the very poor quality. When the commodity was weighed a conflict arose, the trader refused to pay the rate of 4000 rupees. The farmer then called some goons in the yard premises and they started threatening the trader"

The immediate outcome of such a quality manipulation is a conflict between farmers and traders. Such conflicts are resolved through the intermediations of the government officers. In the long term however, such manipulations result in a trust deficit between the stakeholders as well as the information systems. The current project implementation ignores quality manipulations by the farmers and hence no quality assessment mechanism has been introduced. This was aptly mentioned by a government officer who mentioned that:

"The farmer does not have grading equipment for these different commodities. So if we can install these different grading machines in the yard. Such conflicts will be reduced. So computerization should look into these aspects also".

Also the farmers sometimes sign auction contracts with more than one trader. An auction contract is a binding agreement between the trader and the farmer. Farmers sign multiple contracts and sell the commodity to the trader that offers the best rate. Various contextual factors force the farmers to choose this strategy. Sometimes because of the huge crowd, the auctions are conducted in haste by the government officers and farmers do not get sufficient time to consider the suitability of the rates. Often farmers are not aware about their right to cancel the auction contract in situations of unsatisfactory rates. Moreover, the process of cancellation requires that the farmers write an application. Given their literacy levels, most of the farmers are uncomfortable with writing such applications. Also the process of cancellation is a bureaucratic procedure and the already exhausted farmer naturally desists from it. This strategy has a negative impact on the success of the information system as it results in massive 
data reconciliation problems. This is because multiple contracts are issued but only few fulfilled. One government officer explained this as under:

"It is quite common here that the farmers do not respect their auctions contracts. If the prices increase they re-auction their commodity and don't cancel their previous contracts. This has implications on the other yard processes as two contracts exist for single transaction".

In the long run this results in the trust deficit between the stakeholders which has negative impact on the information system.

\subsection{Trader Strategies}

Apart from the farmers, the traders also resort to various strategies that have a negative impact on success of information system. They smuggle the commodity in the adjoining states without paying appropriate service charges for them. One of the private partner respondents explained how the traders implemented this strategy:

"See the traders usually export common commodities such as wheat, soya bean, etc to the adjoining states. They pay all the service charges and taxes for these commodities. But often within these commodities they keep a few bags of commodities that are highly priced such as poppy seeds. The check post inspectors neither have the time nor the resources to verify each commodity bag. They just ensure that the vehicles have all required documents. Thus the high priced commodities are smuggled to the other states without any service charge or tax paid on them".

The current information system does not have the ability for physical verification of the commodities at the check posts. The strategy has a negative impact on the success of information system as the government officers are helpless in curbing the smuggling by the traders.

Another strategy of the traders that has direct negative impact on IS success is under reporting of their trade transactions. This reduces their service charge payments. Such a strategy has a negative impact on information system as it creates massive problems of data reconciliation. A private partner employee described the mechanism of under reporting by the traders as under:

"It's common in the yards that traders do not accurately report the commodity prices. The traders need a tax paid certificate in order to sell the commodity forward. This certificate is issued for the quantity of a commodity. The traders report that the commodity was purchased at a very low cost and show a higher stock. Such manipulations get highlighted only when we scrutinise the computerised record. It's only then we realise that the trader had purchased, for example, only 50 quintal of a commodity but has exported 80 quintals. For example the usual rate of garlic is around 1800 rupees a quintal. But those who do the manipulations of weight and commodity, they report the rate at around 300 to 400 rupees per quintal. They show an increased stock to adjust their unrecorded transactions".

There are certain contextual factors that allow the traders to continue with such strategies. The policy of the board requires that income of the employees should be generated through their respective yards. The income of the yards directly depends on the service charge payments of the traders. This makes the government officers vulnerable to corruption. Secondly the yards had been operated manually for a long time. The crowd situations in the yards have made it very difficult to monitor all the 
transactions of the traders. Consequently the traders have become habituated to submit records as per their will. The current information system changes this situation as the records of traders are available with the click of the mouse. Obviously the traders have opposed the introduction IS in certain yards. One of the private partner employees mentioned that:

"In some yards the commodities with high monetary values are traded and we need to exercise a lot of vigilance and caution there. At some occasions our employees were physically threatened. If you try to help them (traders) understand the rationale of computerization, they say that we are least interested in understanding this. They say we do not want to know about your system. They want that the documentation should be done as per their will. They submit the records as they want, and care least about the rules, regulations and law".

Also the traders have strong links with the other power groups such as politicians and the press. This accentuates their power and motivates them further to use negative-impact strategies. Overall the employment of such strategies results in a lack of sense of ownership amongst the stakeholders. The trust deficit further motivates the stakeholders to use negative impact strategies thereby jeopardising the success of IS.

\subsection{Private Partner Strategies}

The private partners that are implementing the information system also employ various negative impact strategies. The private partner's objective is profit maximization through service delivery. Cost reduction contributes to it. One ways to reduce the cost is to deploy fewer human resources. Another way is to deploy lowly skilled human resources. The private partners use both these strategies. This has serious negative implications on the success of information system because the fundamental tasks such as data entry are not done properly. According to one government officer, often the private partner does not provide the number of employees as agreed in the contract. The government officer explained this as under:

"The commodities of the farmers are weighed at the weigh points. I have over fifty such weigh points in this yard. If the private partners need actual data from the field, they have to employee around fifty people with the hand held terminals here to capture the live data. Moreover they will need some people at the auction spot. This will create a requirement of around 60 people here. But they have deployed only 10-12 people. So they deploy lesser staff and use our records for entering the data".

Another employee described this situation as under:

"Contractors in India usually have a tendency to minimise the expenditure irrespective of its impact on the quality. So that's what happening here with the private partner. They are minimising their cost by staffing lower quality of staff and lesser number of employees."

Another strategy of the private partner is to misinterpret the reports generated by the IS. This has negative impact on the overall trustworthiness of the information systems. The managers obviously question credibility of the information generated from the information system. This was explained by one of the government officer as under: 
"I will give you one more example of the kind of tricks that private partners play to prove the effectiveness of the IS. The traders submit their records of the transaction usually after ten days. For instance for the trade done between the 1st and 10th of a month, the trader submits the record on 11th. Similarly for the next 10 days, the records are submitted after 20th. Obviously if you check the computerized records on the fifteenth, it will show that some traders have not paid their service charges. So the private partner reports a recovery from the trader, when in effect the truth is that the trader has not yet submitted the records. So the private partners do such false reporting to show that the IS has been successful in recovering the service charge payments".

The choice of such negative strategies results in trust deficit between the government officers and the private partners. This has negative consequences on the success of information system.

\subsection{Government Officer Strategies}

In dealing with the other stakeholders, particularly the traders and farmers, the government officer's decision making is influenced by factors that are above the rules and regulations of the market. Over the years the officers have developed a strategy of first acquiring the knowledge about the background of the person and then dealing with his concerns. The issues are not resolved as per the applicable rules. The impact of such a strategy is that the expectation of transparency due to IS intervention is lost. One of the government officers was frank to admit this and mentioned that:

"This organization presents a classic case of working of a government functionary. Any person is scot free here. He can behave the way he likes to. Here if there is slightest problem in any process such as auction or weighing, then the person comes here to fight with me. They know that they are talking to a government officer and so he can be suppressed. They can make my complaint any time and so they come here and start fighting. So what I have to do is that I need to look at the overall background of the person and then I have to deal with him. If he has a political background, he needs to be treated differently. So I have to look at the background of the person first and the booklet on the rules and regulations of market is kept aside. See we run this place with our tact and not with the Act".

Often the senior government officers have developed a strategy of dealing their subordinates with apathy. This was mentioned by one government officer as under:

"So in India no one thinks about these matters. Our work is not even analyzed, forget about appreciation. I am almost going to complete about two years in this yard and in this duration none of my seniors have given me any feedback about my work."

This has negative impact on IS implementation as the organizational prerequisites of structural changes are not met. The rigid bureaucracy results in a lack of sense of belonging and ownership. This creates a trust deficit and further motivates the stakeholders to employ negative impact strategies. The recursive relationship between these factors and negative impact strategies is presented in Figure 4 below: 


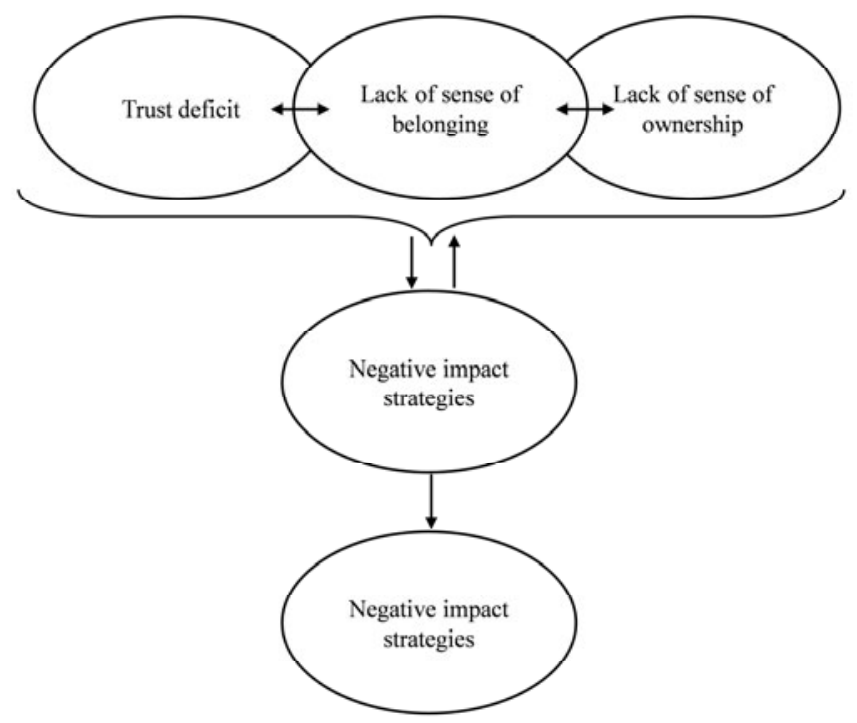

Fig. 4. Recursive relationship between negative impact strategies and trust deficit, sense of belonging and ownership

\subsection{Attributes of Negative Impact Strategies}

We have seen that the stakeholders use various strategies that have a potentially negative impact on IS success. These range from smuggling the commodities to showing apathy to the subordinates. We next present some attributes that are common in the various negative impact strategies:

1. Crowd Situations: Negative impact strategies are employed in crowd/ haste situations. For example in the current study, it is observed that due to huge crowd at the entrance/ exit gate of the yard, it often becomes difficult to track the entries/ exit of the commodities from the yard. This situation is exploited by the traders to under report their commodities. This attribute has direct application in ICT4D projects as most of such projects are implemented in crowd situations. For the IS to be successful, it becomes important that such crowd situations should be avoided by emphasis on queue management techniques.

2. Time value of commodity: The choice of a negative impact strategy is also determined to some extent by the future value of the commodity. If a positive/ neutral strategy, such as stocking, involves a commodity that loses its economic value with the passage of time, then a stakeholder is likely to choose a negative impact strategy. Farmers, for example, often stock their commodities. In some commodities such as soy bean and wheat, stocking results in the loss of lustre of the commodity. The commodity thus loses its value. In such cases farmers manipulate their qualities by mixing the old stock with the fresh stock. In agricultural marketing information systems, this attribute is of particular interest.

3. Non-Retractability and involvement of other stakeholders: Negative impact strategies are either not completely retractable or retractable only after considerable 
resources have been exhausted. For example, a farmer who mixes two different commodities of wheat cannot retract. The retraction is possible, only by deploying considerable effort or technological resources. Moreover this retraction requires involvement of other stakeholders. A farmer may sign multiple auction contracts but if he chooses to get these cancelled; he needs to submit an application to the government officers. It is only after their approval that such contracts can be cancelled.

Of these attributes some are of immense practical significance. For example the attribute related to crowd situations. Earlier studies from developing countries have revealed that queue management does have a positive impact on IS implementation (Bhatnagar, 2007 pp 22). Retraction of negative impact strategies requires the involvement of other stakeholders. Thus it is important to identify processes that involve multiple stakeholders.

\section{Discussion and Conclusions}

Information systems projects in developing countries have a record of being implemented in an ad hoc manner (Bailur, 2006). In ICT4D projects that involve multiple stakeholders, an understanding of these strategies can provide an effective tool in understanding how these strategies can have positive or negative impacts on the success of the system. It is to be noted that the most of the negative impact strategies not only seem to be against the existing rules and regulations but also are unethical. In the current case various strategies such as smuggling of the commodities, under reporting the trade transactions, quality manipulations, etc have not been fully brought under the scope of IS. Given that this project is the first government owned agricultural marketing information system project in India and that other states are likely to follow its implementation, one idea would be to design the IS so as to curb the negative impact strategies of the stakeholders.

We acknowledge various limitations of the current study. First, the study is India specific. Though past studies on agricultural marketing in developing countries reveal common issues (FAO, 2001; A. Shepherd, 2005; A. S. Shepherd, 1997 ), yet agriculture in India may have some unique characteristics. Second, the results from the study are specific to agricultural marketing information systems. Urban ICT4D projects will have different stakeholders and hence there will be variations in the strategies. However, we believe that the overall approach of studying stakeholder strategies might well be relevant for the design and implementation of ICT4D projects in other countries and different industries.

\section{References}

Avgerou, C.: Information systems in developing Countries: a critical research review. Journal of Information Technology 23, 133-146 (2008)

Bailur, S.: Using Stakeholder Theory to Analyze Telecenter Projects. Information Technologies and International Development 3(3), 61-80 (2006) 
Best, M., Kumar, R.: Sustainability Failures of Rural Telecenters: Challenges from the Sustainable Access in Rural India (SARI) Project. Information Technologies and International Development 4(4), 31-45 (2008)

Bhatnagar, S.: Impact Assessment Study of Computerised Service Delivery Projects from India and Chile. IT at World Bank, Staff Working Paper (42147), 2 (2007)

Cavaye, A.L.M.: Case study research: a multi-face-ted research approach for IS. Information Systems Journal 6, 227-242 (1996)

Ciborra, C.: Interpreting e-government and development: Efficiency, transparency or governance at a distance? Information Technology and People 18(3), 260-279 (2005)

DIT. Draft Report on Impact Assessment of e-Governance Projects. Depertment of Information Technology, Government of India, New Delhi (2008)

FAO. Information and communication technologies servicing farm radio: New contents, new partnerships. Paper presented at the International Workshop on Farm Radio Broadcasting, Rome, Italy ( February 19-22, 2001)

Frooman, J.: Stakeholder Influence Strategies. Academy of Management Review 24(2), $191-$ 205 (1999)

Frooman, J., Murrell, A.J.: Stakeholder Influence Strategies: The Roles of Structural and Demographic Determinants. Business Society 44(3) (2005)

Heeks, R., Arun, S.: Social outsourcing as a development tool: The impact of outsourcing it services to women's social enterprises in Kerala. Journal of International Development 22(4), 441-454 (2010)

Hendry, J.R.: Stakeholder Influence Strategies: An Empirical Exploration. Journal of Business Ethics 61, 79-99 (2005)

Kaler, J.: Morality and Strategy in Stakeholder identification. Journal of Business Ethics 39, 91-99 (2002)

Klein, H., Myers, M.: A set of principles for conducting and evaluating interpretive field studies in information systems. MIS Quarterly 23(1), 67-93 (1999)

Krishna, S., Walsham, G.: Implementing public information systems in developing countries: Learning from a success story. Information Technology for Development 11(2), 123-140 (2005)

Kumar, R., Best, M.: Impact and Sustainability of E-Government Services in Developing Countries: Lessons Learned from Tamilnadu, India. The Information Society 22, 1-12 (2006)

Kumar, R., Best, M.L.: Impact and sustainability of E-government services in developing countries: Lessons learned from Tamil Nadu, India. Information Society 22(1), 1-12 (2006)

Lewis, D., Madon, S.: Information systems and nongovernmental development organizations: Advocacy, organizational learning, and accountability. Information Society 20(2), 117-126 (2004)

Lyytinen, K.: Expectation failure concept and systems analysts view of information system failures: Results of an exploratory study. Information \& Management 14(1), 45-56 (1988)

Lyytinen, K., Hirschheim, R.: Information failures-a survey and classification of the empirical literature. Oxford Surveys in Information Technology 4, 257-309 (1987)

Mellahi, K., Wood, G.: The Role and Potential of Stakeholders in "Hollow Participation": Conventional Stakeholder Theory and Institutionalist Alternatives. Business \& Society Review 108(2), 183-202 (2003)

Mitchell, R.K., Agle, B.R., Wood, D.J.: Toward a theory of stakeholder identification and salience: Defining the principle of who and what really counts. Academy of Management Review 22, 853-886 (1997) 
Myers, M.: Qualitative Research in Business \& Management. Sage publications, London (2009)

Nandhakumar, J., Jones, M.: Too close for comfort? Distance and engagement in interpretive information systems research. Info Systems Journal 7, 109-131 (1997)

Orlikowski, W.J., Baroudi, J.: Studying information technology in organizations: research approaches and assumptions. Information Systems Research 2(1), 1-28 (1991)

Phillips, R., Freeman, R.E., Wicks, A.C.: What Stakeholder Theory Is Not. Business Ethics Quarterly 13(4), 479-502 (2003)

Preston, L.E., Sapienza, H.J.: Stakeholder management and corporate performance. Journal of Behavioral Economics 19(4), 361-375 (1990)

Scholl, J.H.: E-government: A Special Case of ICT-enabled Business Process Change. Paper presented at the Proceedings of the 36th Hawaii International Conference on System Sciences (2002)

Shepherd, A.: Bringing market information to farmers: opportunities through FM radio, vol. 9. Agricultural Support Systems Division, FAO, Rome (2005)

Shepherd, A.S.: Market Information Services: Theory and Practice Rome: FAO (1997 )

Singh, B.: Whither Agriculture in India. N. R. Agrawal \& Company, India, Agra (2007)

Walsham, G.: Doing interpretive research. European Journal of Information Systems 15, 320330 (2006)

Walsham, G., Sahay, S.: GIS for district-level administration in India: Problems and opportunities. MIS Quarterly: Management Information Systems 23(1), 39-66 (1999)

Walsham, G., Sahay, S.: Research on Information Systems in Developing Countries: Current Landscape and Future Prospects. Information Technology for Development 12(1), 7-24 (2006)

Zietsma, C., Winn, M.I.: Building chains and directing flows: Strategies and tactics of mutual influence in stakeholder conflicts. Business and Society 47(1), 68-101 (2008) 